\title{
HUMAN PAPILLOMAVIRUS TYPE 6 AND 11 IN LARYNGEAL PAPILLOMAS
}

\author{
Shuichi Watanabe ${ }^{1)}$, Yoshihiro Naito ${ }^{1)}$, Takashi Kawakami ${ }^{1)}$ \\ Kunihiro Fukushima ${ }^{1)}$, Yu Masuda ${ }^{1)}$, Ryusuke Saito ${ }^{2)}$ \\ ${\text { Hajime } \text { Ogura }^{3)} \text {, Tazuko Fujiwara }}^{3)}$ and Yoshiro Yabe ${ }^{3)}$
}

喉頭乳頭腫，喉頭ポリープにおけるヒト乳頭腫ウイルス（6，11型）の検索

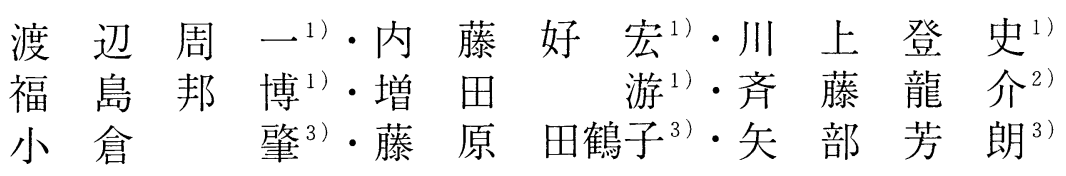

喉頭乳頭腫の発生にヒトパピローマウイルス (HPV) が深く関与していることが示唆されている.今回われわ れは，喉頭乳頭腫の病因的役割を検討する目的で 5 例（若年性 3 例，成人性 2 例）の喉頭乳頭腫と 5 例の声帯ポリ ープを病理組織学的, 免疫組織化学的及び分子生物学的手法を用い HPV 検出を試みた。喉頭乳頭腫では, dot blot 法, Southern blot法により 4/5にHPV DNA が検出され, Southern blot 法によりそのタイプは HPV-6 (2 例), HPV-11 (2 例) と判明した。また HPV DNA 陽性例のみウイルス感染に特徵的な細胞形態学的変化 (koilocytosis) がみとめられその臨床分類はすべて多発性であり年齢との相関はみとめられなかった。免疫組織 化学検査での papillomavirus genus specific common antigenの検出はすべて陰性となり, 感受性の低さがそ の原因と考えられた。声帯ポリープでは，dot blot法で2例の陽性例があったがSouthern blot法では HPV DNA 陰性であり，偽陽性の反応とする方が妥当と結論した.

Key Words : Laryngeal Papilloma, Human Papillomavirus, Molecular hybridization, Immunohistochemistry, Koilocy tosis

\section{Introduction}

More than sixty different types of the human papillomaviruses (HPV) have been found so far ${ }^{1)}$. It has been proved that some of them are specifically and closely associated with certain benign or malignant tumors of dermatological and gynecological origin. Recently, data showing the presence of HPV genome in head and neck tumors are accumulating $^{2 \sim 5)}$

Papillomas are the most frequent laryngeal tumor and it is well known that multiple laryngeal papillomas are recurrent and resist treatment. We attempted to confirm the etiological role of $\mathrm{HPV}$ in laryngeal papilloma, using the techniques of histopathology, immunohistochemistry, dot blot and Southern blot hybridization. Laryngeal polyps were also examined as a control. Among these HPV detection methods, Southern blot hybridization is the most reliable technique, and furthermore, classification of HPV is also possible. The identification was homology with molecular cloned probes under stringent conditions.

\section{Materials and Methods}

\section{Papilloma and polyp samples}

The present series consists of 5 patients of laryngeal papilloma and 5 patients of laryngeal polyp operatively treated at the Department of Otolaryngology, Okayama University Medical School, during the years 1981 to 1990. A part of each papilloma was fixed and processed for light microscopic examination and the rest of the unfixed samples was kept frozen at $-70^{\circ} \mathrm{C}$ until this study. The diagnosis of

1 ) 岡山大学医学部耳鼻咽喉科学教室

2 ) 岡山済生会病院耳鼻咽喉科

3 ) 岡山大学医学部癌源研究施設ウイルス部門

1) Department of Otolaryngology, Okayama University Medical School, Okayama

2 ) Section of Otolaryngology, Saiseikai General Hospital, Okayama

3 ) Department of Virology, Cancer Institute, Okayama University Medical School, Okayama 
every tumor was confirmed by histological examination. Age, sex and clinical features of the patients are summarized in Tabel 1.

\section{Histopathology}

Each sample stained with hematoxylin-eosin was examined for the histomorphological change characteristic of HPV infection, or koilocytosis, under light microscope.

\section{Immunohistochemical staining}

Sections prepared from paraffin-embedded specimens were dewaxed with xylene and ethanol. Endogenous peroxidase activity was eliminated by $0.3 \% \mathrm{H}_{2} \mathrm{O}_{2}$ treatment for $30 \mathrm{~min}$. at room temperature. After the procedure, each section was treated with $0.1 \%$ trypsin at $37^{\circ} \mathrm{C}$ and washed with $0.1 \% \mathrm{NaN}$-containing fetal calf serum. The papillomavirus genus specific antigen (pgs-antigen) was detected by commercially available antibody from DAKO Company (Denmark). The antibody was diluted 500 times and reacted with each section for $60 \mathrm{~min}$. at room temperature. After being washed by phosphate buffered saline with detergent, these sections were reacted with horseradish peroxidase-labeled, anti-rabbit IgG, goat IgG for $30 \mathrm{~min}$. at room temperature. After the treatments, sections were stained with buffer containig $\mathrm{H}_{2} \mathrm{O}_{2}$ with diaminobenzidin and hematoxylin for morphological study. As a positive control, a case of verruca vulgaris positive for pgs-antigen was included in this test.

\section{Dot blot hybridization}

The dot blot hybridization kit, vira probe HPV, was obtained from Life Technologies Inc., (U.S.A.) through Toray-Fuji Bionics Inc.,(Japan). The RNA cocktail probe of HPV types 6, 11, 16, 18, 31, 33 and 35 was labeled with ${ }^{32} \mathrm{P}$.

Tumor material was thawed, cut into small pieces with scissors, ground in a precooled mortar with quartz and incubated at $37^{\circ} \mathrm{C}$ for $6 \mathrm{hrs}$ in a $3 \%$ lysis solution containing $250 \mu \mathrm{g} / \mathrm{ml}$ proteinase K (Sigma, W. Germany), $1 \%$ sodium dodecyl sulfate in TE buffer (10 mM Tris-HC 1, pH 8.0, and $1 \mathrm{mM}$ ethylenediamine tetra-acetate). Two hundred and fifty microliters of the homogenate solution was tested by dot blot hybridization after alkaline denaturation as indicated by the manufacturer.

\section{Extraction and digestion of DNA}

Extraction and purification of DNA from tissue homogenate were performed by phenol extraction and RNase treatment. Digestion of DNA with endonucleases BamHI (Boegringer Mannheim,W.Germany), and Hind II (Takara, Kyoto, Japan) was performed according to the methods indicated by the manufacturer.

Nonradioactive DNA labeling and Southern blot hybridization

The HPV type 11 DNA was cloned in pBR322 in this laboratory. The HPV type 16 and 18 DNA in pBR322 were the generous gift of Dr. E.-M.deVilliers, Heiderberg, W.Germany. The DNA probes of HPV type 11,16 and 18 were separated from vector pBR 322 and labeled with digoxigenin-deoxyuridine triphosphate using the kit prepared by Boehringer Mannheim, W.Germany.

Electrophoresis of each endonuclease-digested DNA was done in $0.8 \%$ agarose gel in $\mathrm{TEA}-\mathrm{NaCl}$ buffer (50 mM Tris- $\mathrm{HCl}$, pH8.0, containing $20 \mathrm{mM}$ sodium acetate, $2 \mathrm{mM} \mathrm{Na}_{2} \mathrm{EDTA}$ and $18 \mathrm{mM} \mathrm{NaCl}$ ). After gel electrophoresis, DNA was transferred to Nytran membrane (Schneider and schuell, Passel, W.Germany) by Southern blotting. After hybridization under stringent conditions, the detection of hybrids to the target DNA by enzyme-linked immunoassay using an antibody-conjugate and subsequent enzyme catalyzed colour reaction with 5-bromo-4-chloro-3-indolyl phosphate and nitroblue tetrazolium salt was performed according to the manual prepared by the manufacturer.

\section{Results}

\section{Histopathology}

Koilocytosis, defined as large epithelial cells with vacuolated cytoplasm and an eccentric pyknotic nucleus, were identified in 4 of 5 laryngeal papillomas (Fig 1). These 4 samples with koilocyte were all multiple type (Table 1).

In laryngeal polyps, no koilocyte was identified. Five laryngeal papillomas and 5 laryngeal polyps were investigated immunohistochemically for pgsantigen. No cell with a pgs-antigen-positive nucleus was detected in any of these lesions. Many pgs-antigenpositive cells, however, were detected in the superficial layers and in the intermediate layers (not shown) in the specimens of verruca vulgaris used as positive control.

\section{HPV detection by dot blot hybridization}

Fig 2. shows an autoradiogram obtained after dot blot hybridization using ${ }^{32} \mathrm{P}$-labeled vira probe HPV. Hela cell DNA containing HPV 18 DNA hybridized with vira probe HPV (Fig 2.A) while HTB-31 cell DNA containing no HPV DNA (Fig 2. B) and 


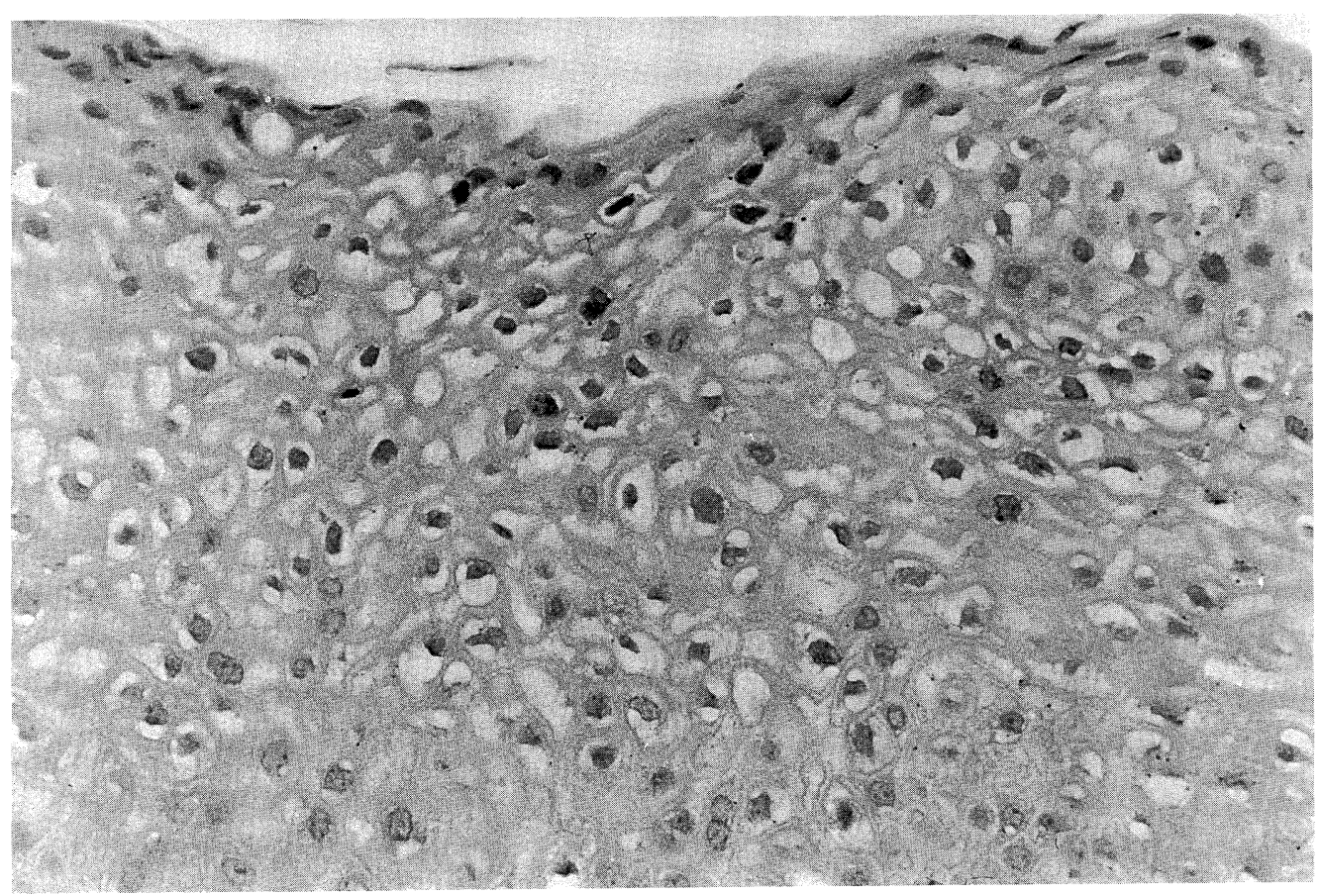

Fig.1 Histopathology of laryngeal papilloma. Note the koilocytosis.

Table 1 Search for HPV in Laryngeal Papillomas and Polyps

\begin{tabular}{ccclccc}
\hline \hline Papilloma Case & Sex & Age at Biopsy & $\begin{array}{l}\text { Clinical } \\
\text { Feature }\end{array}$ & D.B. & S.B. & Koilocytosis \\
\hline 1 & M & 2.5 & multiple & + & HPV-6 & + \\
2 & M & 5 & multiple & + & HPV-11 & + \\
3 & M & 6 & multiple & + & HPV-11 & + \\
4 & M & 28 & multiple & + & HPV-6 & + \\
5 & M & 58 & Single & - & - & - \\
Polyp Case & & & & & & \\
\hline 1 & M & 24 & & + & - & - \\
2 & F & 34 & & + & - & - \\
3 & F & 44 & & - & - & - \\
4 & M & 50 & & - & - & - \\
5 & M & 59 & & - & - & - \\
\hline
\end{tabular}

$\mathrm{M}:$ male $\mathrm{F}$ : female D.B. : Dot blot hybridization

S.B. : Southern blot hybridization 


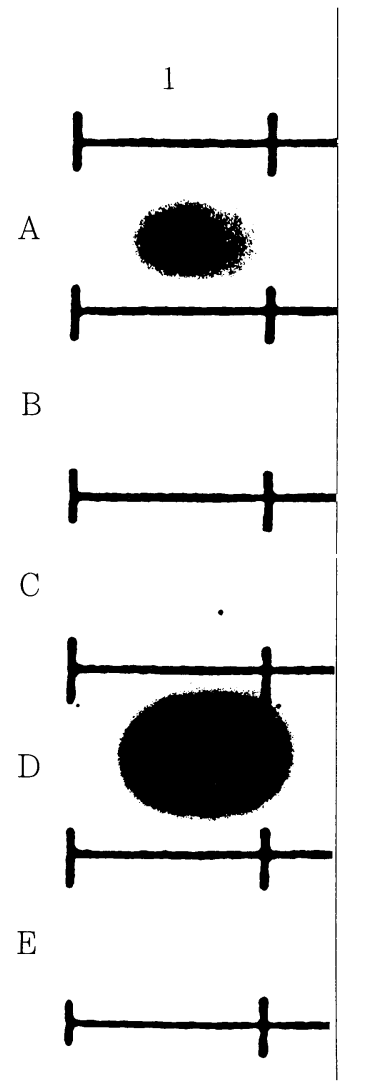

Fig.2 Detection of HPV by dot blot hybridization whole cellular DNA was hybridized with ${ }^{32} \mathrm{P}$ labeled HPV RNA probe,

A : positive control of Hela cell DNA containing HPV 18 DNA.

B : negative control of HTB-31 cell DNA containing no HPV DNA.

C : negative control of pBR322 DNA (100ng).

D : HPV DNA detection in whole DNA of a laryngeal papilloma.

E : HPV DNA negative sample of a laryngeal polyp.

pBR322 DNA (100ng) (Fig 2.C) did not. One of laryngeal papilloma DNA hybridized with vira probe HPV showing black spot (Fig 2.D). Four cases out of 5 laryngeal papillomas were HPV-DNA positive by this method (Table 1). These 4 cases were all multiple type and koilocytosis-positive (Table 1). Two cases out of 5 laryngeal polyps were also positive by this method (Table 1 ).

\section{HPV detection of Southern blot hybridization}

Endonuclease Bam $\mathrm{Hl}$ digested DNA isolated from laryngeal papillomas and laryngeal polyps was electrophoresed, Southern blotted and hybridized with digoxigenin-dUTP-labeled DNA mixture of HPV 11, 16 and 18. As is shown in Fig. 3, a band of $7.5 \mathrm{~kb}$ was detected in lane 1 and 5. All 4 laryngeal papillomas which were positive by dot blot hybridiza-

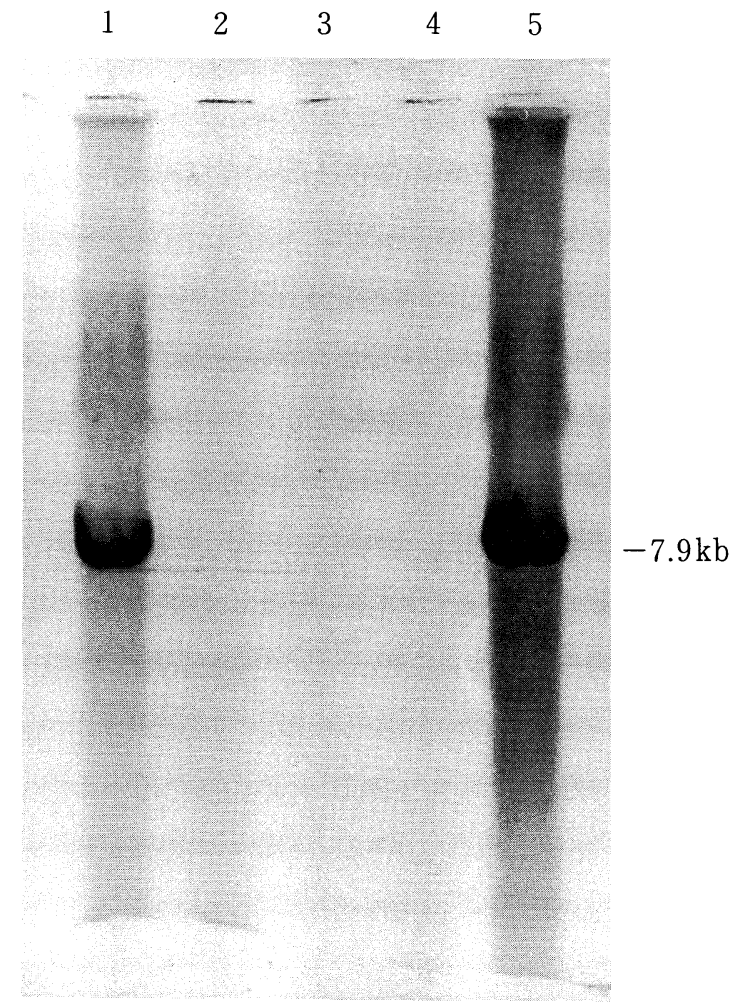

Fig.3 Detection of HPV DNA by Southern blot hybridization after Bam Hl cut. DNAs isolated from laryngeal papilloma and laryngeal polyp were cleaved by Bam $\mathrm{Hl}$ and hybridized with digoxigenin-dUTP labeled DNA mixture probe of HPV type 11, 16 and 18. Lane 1 and 5 show HPV DNA band of $7.9 \mathrm{~kb}$. Size marker was HPVIIDNA.

tion were also positive and one negative sample by dot blot hybridization was negative by this method. Two HPV-positive laryngeal polyps by dot blot hybridization were negative by Southern blot hybridization (Table 1). HPV-DNA detected in laryngeal papillomas was further analysed by Hind II digestion and hybridization with HPV 11 probe. Hind II cuts HPV 6 DNA into 2 fragments, one of which is sometimes not visible because of its small size and amount, and cuts HPV 11 DNA into 4 fragments ${ }^{6,7)}$. Fig. 4 lane 2 shows HPV 6 DNA closely related with HPV 11 DNA and Fig. 5 lane 2 shows HPV 11 DNA cut by Hind $I$. The results are summarized in Table 1 .

\section{Discussion}

Cutaneous and genital warts have been extensively studied virologically and the role of HPV as an etiological agent has been established ${ }^{6,8,9,10)}$.

As laryngeal papilloma resembles cutaneous and genital warts histopathologically, HPV infection as a cause of this benign tumor has been speculated 


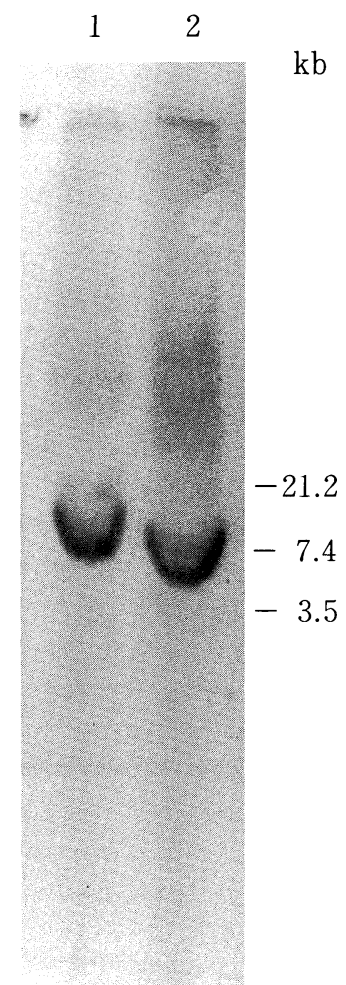

Fig.4 Detection of HPV 6 DNA

DNA was cleaved by Bam H1(lane 1) and Hind II (lane 2), and hybridized with digoxigenindUTP labeled HPV 11DNA. Note the Hind II cleavage pattern characteristic for HPV 6 DNA which is closely related to HPV 11 DNA. Size marker was EcoRl cleavaged $\lambda$ DNA.

and studied ${ }^{7,11,12,13)}$. In this paper we examined the presence of HPV in laryngeal papillomas and in laryngeal polyps as control. Histopathology, immunohistochemistry and molecular hybridization by dot blot as well as Southern blot have been included in this study.

Koilocytosis was observed in all HPV positive papillomas but not in polyps. Ferenczy et al ${ }^{14)}$ reported that in condyloma of the genital tract, a presumed viral replication within the cells near the epithelial surface results in a characteristic degeneration of nuclear chromatin. Koilocyte is manifested as large epithelial cells with vacuolated cytoplasm in superficial cell layers. We agree that the presence of koilocytes provide indirect evidence of HPV infection.

We attempted to detect HPV pgs-antigen in laryngeal papilloma by the immunohistochemical method. Though this method worked well in a specimen of verruca vulgaris, no positive result was obtained in specimens of laryngeal papillomas. It has also been reported by other groups that the sensitivity of the

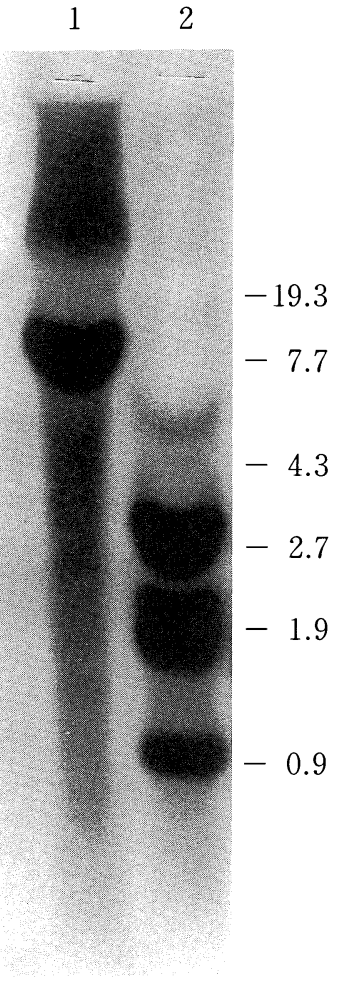

Fig.5 Detection of HPV 11DNA

DNA was cleaved by BamH1 (lane 1), Hind II (lane 2), and hybridized with digoxigenin-dUTP labeled HPV 11 DNA. Note the Hind II cleavage pattern characteristic for HPV 11DNA. Size marker was EcoT141 cleaved $\lambda$ DNA.

immunohistochemical method in cases of laryngeal papilloma was low ${ }^{15,16,17)}$. This may be due to the low production of HPV capsid antigen in the infected cells as well as the small number of infected cells in case of laryngeal papilloma when compared with verruca vulgaris.

To prove the presence of HPV genome directly, we applied dot blot and Southern blot hybridization method. The dot blot hybridization method used in this study was a commercially developed HPV-screening kit. Tissue homogenate treated with proteinase $\mathrm{K}$ without DNA isolation was applied, and the result agreed completely with that of Southern blot hybridization in laryngeal papillomas. However, no HPV DNA band was detected by Southern blot hybridization in purified DNA of $2 \mathrm{HPV}$-positive laryngeal polyps by dot blot hybridization. As the Southern blot hybridization is the most reliable method, these 2 HPV-positive cases by dot blot hybridization seem to be false positives, although the possibility of the presence of HPV other type than $6,11,16$ and 18 was not excluded. The etiology 
of laryngeal polyp is thought to be local circulatory insufficiency due to overwork of vocal cords.

The fact that every multiple type of laryngeal papilloma contains HPV 6 or 11 while no laryngeal polyp does, supports the etiological role of HPV in laryngeal papilloma. In this study, confirming the reports of other groups ${ }^{10,11,12)}$, HPV type 6 in 2 cases and HPV type 11 in 2 cases were detected. There were no recognizable differences in histological features, age of onset or clinical course between HPV 6 and 11 infections.

\section{Conclusion}

This work was undertaken to study the etiological role of HPV in laryngeal papilloma.

Five cases of laryngeal papilloma and 5 cases of laryngeal polyp were examined histopathologically, immunohistochemically and molecular biologically. The presence of koilocytosis correlated well with the presence of HPV. Immunohistochemical staining of HPV pgs-antigen was all negative probably due to low sensitivity. In laryngeal papilloma, the results of dot blot and Southern blot hybridization agreed completely and 4 out of 5 cases were HPV positive. HPV type 6 was detected in 2 cases and HPV type 11 also in 2 cases. These $4 \mathrm{HPV}$-positive cases were clinically all multiple type and the HPV negative 1 case was single type. Among laryngeal polyp cases, 2 positive results by dot blot hybridization seemed to be false positive.

\section{Acknowledgments}

We are grateful to Drs. H. zur Hausen and E.M. de Villers for kindly providing us with DNAs of HPV types 16 and 18.

\section{References}

1) de Villiers EM : Heterogeneity of the Human Papillomavirus Group. J Virol 63: 4898 4903, 1989.

2) Loning $\mathrm{T}$ et al : Analysis of Oral Papillomas, Leukoplakias, and Invasive Carcinomas for Human Papillomavirus Type Related DNA. J Investigative Dermatol 84:417 420, 1985.

3) de Villiers EM et al : Papillomavirus DNA in Human Tongue Carcinoma. Int J Cancer 36 : 575 578, 1985.

4) Brandsma JL et al: Association of Papillomavirus with Cancers of the Head and Neck. Arch Otolaryngol Head Neck Surg $115: 621 \sim 625,1989$.
5) Hoshikawa $\mathrm{T}$ et al: Detection of Human $\mathrm{Pa}$ pillomavirus DNA in Laryngeal Squamous Cell Carcinomas by Polymerase Chain Reaction. Laryngoscope 100:647 650, 1990.

6) de Villiers EM et al: Molecular Cloning of Viral DNA from Human Genital Warts. J Virol $40: 932 \sim 935,1981$.

7) Gissman L et al : Molecular Cloning and Characterization of Human Papillomavirus DNA derived from a Laryngeal Papilloma. J Virol $44:$ 393 400, 1982.

8) Lutzner MA : Epidermodysplasia Verruciformis, an Autosomal Recessive Disease Characterized by Viral Warts and Skin Cancer, A Model for Viral Oncogenesis. Ball Cancer (Paris) $65: 169$ 182, 1978.

9) Lutzner MA : The Human Papillomaviruses. Arch Dermatol 119: 631 635,1983.

10) Gissman L et al: Human Papillomavirus Type 6 and 11 DNA Sequence in Genital and Laryngeal Papillomas in Some Cervical Cancers. Proc Nathl Acad Sci USA 80: 560 563, 1983.

11) Mounts Petal: Viral Etiology of Juvenile -and Adult-Onset Squamous Papilloma of the Larynx. Proc Nathl Acad Sci USA 79:5425 5429, 1982.

12) Mounts $P$ et al: Association of Human Papillomavirus Subtype and Clinical Course in Respiratory Papillomatosis. Laryngoscope $94: 28 \sim 33$, 1984.

13) Duggan MA et al: HPV DNA Typing of AdultOnset Respiratory Papillomatosis. Laryngoscope $100: 639 \sim 642,1990$.

14) Ferenczy A et al: Human Papillomavirus(HPV) in Condylomatous Lesions of Cervix. Am J Surg Pathol 5:661 670, 1981.

15) Costa J et al : Presence of Human Papilloma Viral Antigen in Juvenile Multiple Laryngeal Papilloma. Am J Clin Pathol 75 : 194 197, 1981.

16) Braun L et al : Demonstration of Papillomavirus Antigen in Paraffin Section of Laryngeal $\mathrm{Pa}-$ pillomas. Laryngoscope 92:640 643, 1982.

17) Nakajima $\mathrm{T}$ et al : Papillomavirus Infection among Japanese : an Immunohistochemical Study for Papillomavirus Genus-Specific Antigen in Human Surface Epithelial Lesions. Jpn J Cancer Res (Gann) 76:508 516, 1985.

別刷請求先 $\overline{\mathbf{T}} 700$ 岡山市鹿田町 2 丁目5-1 岡山大学医学部耳鼻咽喉科学教室 渡辺周一 